\title{
Floristic Distribution and Heavy Metal Levels Around Auto-Mechanic Workshop Clusters in the Yenagoa Metropolis, Bayelsa State, Nigeria
}

\author{
Bariweni Perekibina Anthony, Amukali Ogochukwu* \\ Department of Geography and Environmental Management, Niger Delta University, Amassoma, Nigeria \\ Email address: \\ amukaliogo@yahoo.com (A. Ogochukwu) \\ ${ }^{*}$ Corresponding author
}

\section{To cite this article:}

Bariweni Perekibina Anthony, Amukali Ogochukwu. Floristic Distribution and Heavy Metal Levels around Auto-Mechanic Workshop Clusters in the Yenagoa Metropolis, Bayelsa State, Nigeria. International Journal of Natural Resource Ecology and Management. Vol. 5, No. 2, 2020, pp. 37-42. doi: 10.11648/j.ijnrem.20200502.11

Received: May 21, 2018; Accepted: June 12, 2018; Published: April 7, 2020

\begin{abstract}
A floristic survey of plant species encountered around auto-mechanic workshop clusters in the Yenagoa Metropolis was conducted using stratified sampling technique and following standard methods in this study. Sampling was done at three intervals; reference point $(0 \mathrm{~m}), 50 \mathrm{~m}$ and $100 \mathrm{~ms}$ from 5 auto-mechanic workshop clusters and a control site. Results were expressed in simple percentages X \pm STD. The distributional patterns, frequency of occurrence and Sorensen's Similarity Index of plant species around auto-mechanic workshop clusters were used to determine prevalence levels and variations from one sample site to another. It was observed that distance decay concept manifested conspicuously as plant species' diversity increased with increasing distances from the reference points $(0 \mathrm{~m})$ of the auto-mechanic workshop clusters. Overall plant species diversity at the reference point $(0 \mathrm{~m})$ was $5 \pm 1,25 \pm 23$ at $50 \mathrm{~m}$ and $36 \pm 12$ at $100 \mathrm{~m}$ around the automechanic workshop clusters while $37 \pm 32$ was observed at the control site, respectively. However, the control site showed highest species' frequency distribution and diversity as compared to the auto-mechanic workshop clusters in this study. Heavy metal levels were generally observed to be higher in soils around auto-mechanic workshop clusters than at the control site showing evidence of anthropogenic effects in samples encountered at the auto-mechanic workshop clusters. $\mathrm{Zn}, \mathrm{Cu}, \mathrm{Cd}, \mathrm{Cr}, \mathrm{Hg}$ and $\mathrm{Mn}$ were noticed to have decreased with increasing distances suggesting distance decay while Ni and Fe increased with increasing distances in soils of the auto-mechanic workshop clusters. These had tremendous effects on the distributional patterns of most plant species in this study. This study has shown that plant species like Sc. dulcis (Scrophuriaceae), $C$. digitalis (Cyperaceae), Py. Polystachyos (Cyperaceae), A. tectorum (Poaceae), P. foetida (Passifloraceae), S. paramidalis (Rubiaceae), as well as C. mucunoides (Febaceae) remain better choices for use as bio-indicators for heavy metal studies around auto-mechanic workshop cluster in the Yenagoa Metropolis since despite exposure to prevailing natural and anthropogenic conditions, they still showed heavy metal tolerance and remediation potentials.
\end{abstract}

Keywords: Species Diversity, Auto-mechanic Workshop Clusters, Heavy Metals, Yenagoa Metropolis

\section{Introduction}

Yenagoa Metropolis has had tremendous increase in population since 1996 after the creation of the state owing to increasing influx of thousands of people from different parts of the country into the area. As human population increased, more mouths ought to be fed and this necessitated more movement of people and goods from one place to another for manifold reasons. Unavoidably, this implied more servicing and repair of automobiles, thus engendering springing up of more auto- mechanic workshop clusters within the Metropolis. Automechanic workshop clusters usually are sited where different plant species grow and these get affected one way or another.

Auto-mechanic workshop clusters are geographical locations specifically inhabited by automobile repair workers in settings suited for different automobile workers who specialize in handling one type of automobile-related issue or the other. It is common knowledge that auto-mechanics, panel beaters, welders, spray painters, vulcanizers, scrap metal dealers, battery chargers and a host of other artisans 
usually conglomerate within auto-mechanic workshop clusters where they render various repairs and services. With functional auto-mechanic workshop clusters in place, car owners are provided with a 'one-stop' service and repair centre for servicing and repair of different faults in their automobiles, thus implying overwhelming advantages in the geographical locations where they are situated.

A look at literature revealed that several authorities have conducted floristic checklist of areas prone to anthropogenic influences in different parts of the world. Reference [10] showed a comprehensive floristic survey to record the botanical diversity, ethnotaxonomy, reproductive as well as the phenological response of the vascular flora of the district Kotli, Azad Jammu and Kashmir in Pakistan between 2011 and 2013. In their study, a total of 463 plant species belonging to 306 genera and 93 families were recorded with the most dominant families in the study area in this order; Poaceae (54 species), Leguminosae (39 species), Compositae (33 species), Lamiaceae (23 species) and Rosaceae (22 species), respectively. Reference [18] documented a floristic checklist of the angiosperm diversity of Bowen University, Iwo, Osun State, Nigeria. In their study, a total of 110 species in 96 genera and 42 families were recorded. Asteraceae, Euphorbiaceae and Poaceae were dominant with 10, 8 and 8 species, respectively. In another related study, [2] consisted of an eco-taxonomic distribution of plant species around auto-mechanic workshops in Asaba and Benin City, both in Nigeria. This study identified and documented oil-tolerant plant species predominant within the study areas.

Information detailing the distributional patterns of flora within and around auto-mechanic workshop clusters within the Yenagoa Metropolis is to the best of our knowledge, very scanty. This survey was designed to provide a checklist of flora found within and around auto-mechanic workshop clusters. It also helped to assess similarities and differences in floristic distribution within and around the auto-mechanic workshop clusters. In addition, it was intended to bridge information gap relative to spatial floristic distribution of different species affected by heavy metal levels within and around the study area. Finally, this study was designed to enable identifying dominant plants species that tolerated heavy metal contamination within the study area.

\section{Methodology}

\subsection{Study Area}

Yenagoa Metropolis is located between latitudes $4^{\circ} 50^{\prime} \mathrm{N}$ and $5^{\circ} 05^{\prime} \mathrm{N}$ and longitudes $6^{\circ} 15^{\prime} \mathrm{E}$ and $6^{\circ} 30^{\prime} \mathrm{E}$ (Figure 1) and lies astride the Epie Creek which empties into the Ekole Creek [5]. According to [20], Yenagoa Metropolis is the most economically buoyant town in Yenagoa Local Government Area and the entire Yenagoa Local Government Area occupies an estimated area of $706 \mathrm{~km}^{2}$. The population of Yenagoa Local Government Area was put at 353,344 people in 2006 comprising 187,791 males and 165,553 females with an annual growth rate of $2.9 \%$ as at the 2006 National Census
[12]. According to [17], the soils of Yenagoa Metropolis predominantly are classified as rain forest soils with the soils constituting over $90 \%$ of the soils which belong to the following Orders; Entisols, Oxisols and Alfisols, respectively. Ibid [17] further stated that soils of the study area originated from alluvial deposits of late Pleistocene and Holocene ages while [16] did state that the soils of the study area are of the hydromorphic type.

The study area is located within humid tropical wetlands whose viability, structure and functional landcover has been badly affected by developmental projects like built up areas [4]. The study area has mean annual rainfall of about $2,539 \mathrm{~mm}$ with average mean temperature of $26.2^{\circ} \mathrm{C}$ with ambient temperature ranging from $24.5^{\circ} \mathrm{C}$ to $32^{\circ} \mathrm{C}$ during wet and $25^{\circ} \mathrm{C}$ to $36^{\circ} \mathrm{C}$ during dry seasons [17]. Rainfall is usually witnessed throughout the year with peaks from June to September, relative humidity usually about $85 \%$ in the wet season and $45 \%$ in the dry season [Ibid, 17], respectively. Reference [14] further stated that vegetation of the study area falls under the fresh water swamp forest which comprises of thick, tall and shady trees, climbers, shrubs and grasses. Others are economic trees like Raffia palm, Oil palm trees, Wild/African Mango, Crocuces, Avengers species and a host of other plants grow there.

\subsection{Sampling Techniques}

Stratified sampling technique was employed in assessing spatial distribution of plants in the study area. The method used by [13] for assessing plant species distribution was adopted in this particular study. In which case, two line transects were cut $50 \mathrm{~m}$ apart along each auto-mechanic workshop clusters sampled from the $(0 \mathrm{~m})$ reference points of each sample point, leaving $10 \mathrm{~m}$ from the margin of each automechanic workshop clusters, and plants were sampled along the line transects at intervals of $10 \mathrm{~m}$ using a $1 \mathrm{~m}^{2} \times 1 \mathrm{~m}^{2}$ quadrant. Each auto-mechanic workshop cluster was sampled twice and plants encountered twice were ignored. The sampling was then extended from the reference point $(0 \mathrm{~m})$ to $50 \mathrm{~m}$ and later $100 \mathrm{~m}$ away from the auto-mechanic workshop cluster and the process repeated in each case. The sampling was conducted at Imgbi, Igbogene, Imiringi, Swali and Etegwe auto-mechanic workshop clusters as well as a control site in a forested and uncultivated forested area along Igbogene-Zarama Expressway (Figure 1). Sampling was carried out between November 2015 to January 2016 and between June to August 2016, respectively. Most of the plants were identified instantly with the help of reference materials by [8] and [6] and a few of those that could not be identified on the field were properly labeled, put in black polyethylene bags and taken to the Department of Biological Sciences Laboratory, Niger Delta University, for proper identification. The similarity between plant diversity between two sites was estimated using the Sorenen's Similarity Index [19] and this is stated below;

$$
\mathrm{SI}=\frac{\mathrm{a}}{\mathrm{a}|\mathrm{b}| \mathrm{c}}
$$

Where;

SI = Sorensen's Similarity Index, 
$a=$ Number of species common to both sites studied,

$\mathrm{c}=$ Number of species present in site $\mathrm{B}$ but not in site A

$\mathrm{b}=$ Number species present in sites A but not in site B

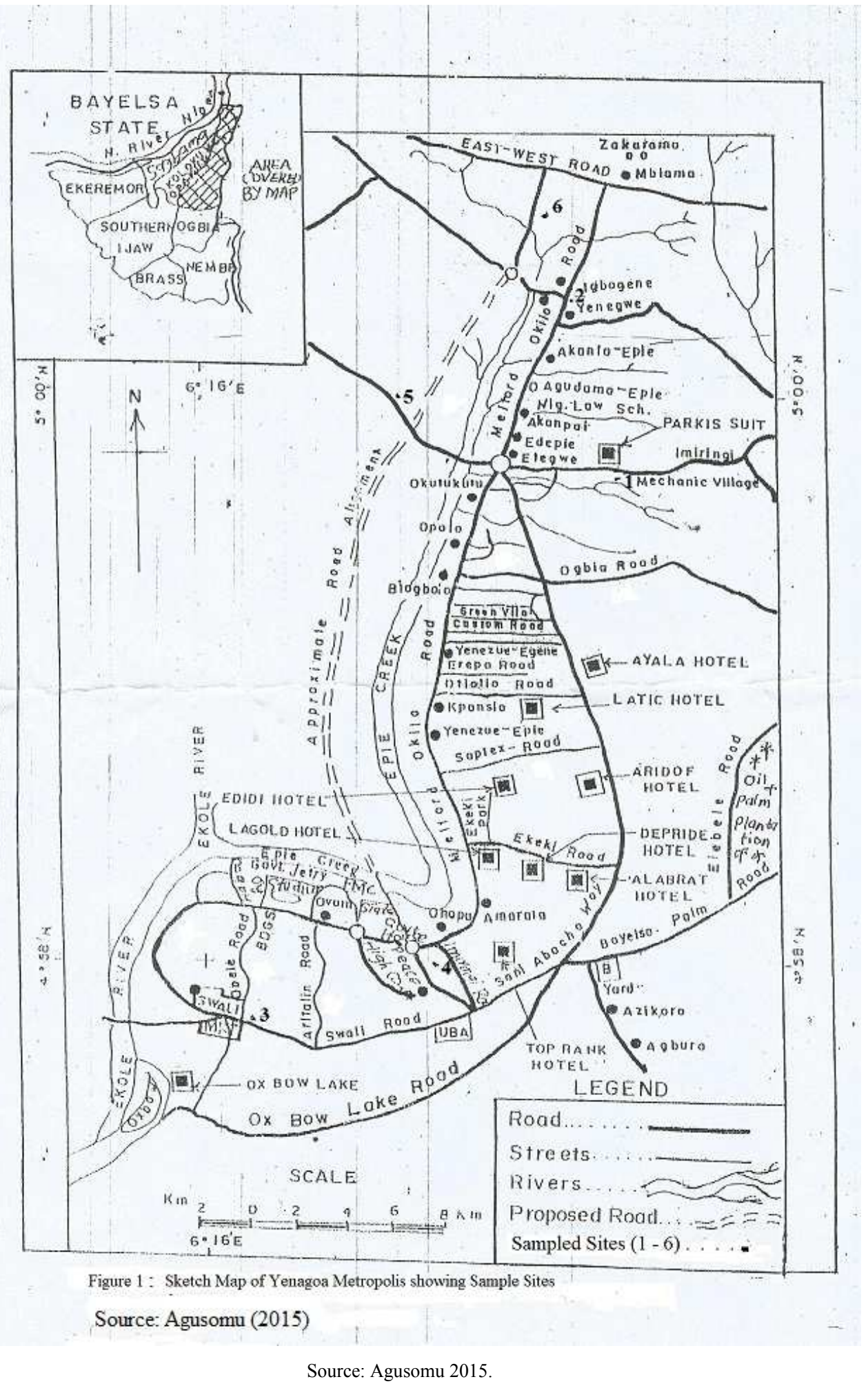

Figure 1. Sketch Map of Yenagoa Metropolis showing sample sites.

\section{Results and Discussions}

Sorensen's Similarity Index consecutively showed infinity for sample sites $0 \mathrm{~m}$ and $50 \mathrm{~m}$ as well as $50 \mathrm{~m}$ and $100 \mathrm{~m}$ at the auto-mechanic workshop clusters in the Yenagoa Metropolis. Generally, it was observed that A. species, U. labata and $C$. doctylon species showed equal mean frequency distributions between the reference points $(0 \mathrm{~m})$ and $50 \mathrm{~m}$ sample site (Table 1). This implied that $A$. species, $U$. labata and $C$. 
doctylon species had good genetic potentials for heavy metal tolerance than other species. Reference [7] earlier reported heavy metal tolerance among the Poaceae family while [2] reported high dominance of $P$. maximum at auto-mechanic workshops at Asaba, Delta State, Nigeria. On the other hand, apart from species of $A$. species, $U$. labata and C. doctylon, it was observed that frequency distributions of all plant species encountered at the auto-mechanic workshop clusters increased with increasing distances from the reference points $(0 \mathrm{~m})$ to farther distances. In which case, lower frequency distributions were generally observed at the reference points $(0 \mathrm{~m})$, then increased gradually at $50 \mathrm{~m}$ and highest at $100 \mathrm{mat}$ the auto-mechanic workshops clusters. As could be seen from Table 1 below, P. maximum (Graminae), C. mucunoides (Febaceae), Sc. dulcis (Scrophuriaceae), P. foetida (Passifloraceae), A. tectorum (Poaceae), S. pyramidalis (Rubiaceae), C. digitalis (Cyperaceae) and Py. Polystachyos (Cyperaceae) all showed fairly higher frequency distributions as one moved from $0 \mathrm{~m}$ to $50 \mathrm{~m}$ and $100 \mathrm{~m}$ in this study. This depicted distance decay effects on plant species distribution around the auto-mechanic workshop clusters in the Yenagoa Metropolis.
Mimosa species and C. prostate were found to be completely absent from the reference point $(0 \mathrm{~m})$ as compared other species which were observed to be conspicuously encountered $50 \mathrm{~m}$ and $100 \mathrm{~m}$ around the auto-mechanic workshop clusters (Table 1). Higher anthropogenic influences at the reference points $(0 \mathrm{~m})$ which necessitated slightly overall higher heavy metal concentrations as compared to farther distances $(50 \mathrm{~m}$ and $100 \mathrm{~m})$ around the auto-mechanic workshop clusters could be responsible for the absence of both species in this present study. However, $C$. odorata (Asteraceae) was observed to be completely absent at the control site but was found to show fair distribution around auto-mechanic workshop clusters in the Yenagoa Metropolis. Two reasons could be responsible for this scenario; either $C$. odorata was naturally not native to the control site or interspecific competition among weed species at the study area could have influenced its absence. In addition, direct anthropogenic influences around automechanic workshop clusters in Yenagoa Metropolis on plant species must have impacted negatively on species distribution of $C$. odorata in this present study.

Table 1. Frequency Distribution of Plant Species within and around Auto-Mechanic Workshops in Yenagoa Metropolis and the Control Site.

\begin{tabular}{|c|c|c|c|c|c|c|c|c|c|c|c|}
\hline \multirow[t]{2}{*}{$\mathbf{S} / \mathbf{N}$} & \multirow[t]{2}{*}{ Plants } & \multirow[t]{2}{*}{ Family } & \multirow[t]{2}{*}{$\begin{array}{l}\text { Uses } \\
\text { Ehigiamusoe } \\
(2013)^{a} \& \text { Gill } \\
(1992)^{b}\end{array}$} & \multicolumn{3}{|c|}{$\begin{array}{l}\text { Frequency } \\
\text { Distribution of Plants } \\
\text { at the AMWs in } \\
\text { Yenagoa Metropolis } \\
(\%)\end{array}$} & \multirow[t]{2}{*}{$\begin{array}{l}\text { Distribution } \\
\text { of Plants at } \\
\text { the Control } \\
\text { Site }(\%) \\
\text { All } \\
\end{array}$} & \multicolumn{3}{|c|}{$\begin{array}{l}\text { Remarks for } \\
\text { Distribution of Plants } \\
\text { at the AMWs in } \\
\text { Yenagoa Metropolis }\end{array}$} & \multirow[t]{2}{*}{$\begin{array}{l}\text { Remarks } \\
\text { for the } \\
\text { Control } \\
\text { Site } \\
\text { All } \\
\end{array}$} \\
\hline & & & & $\mathbf{0 m}$ & $50 \mathrm{~m}$ & $100 \mathrm{~m}$ & & $\mathbf{0 m}$ & $50 \mathrm{~m}$ & $100 \mathrm{~m}$ & \\
\hline 1 & Panicum maximum (Jacq.) & Graminaea & Foliage & $8 \pm 23$ & $46 \pm 52$ & $62 \pm 18$ & $87 \pm 5$ & + & ++ & +++ & ++++ \\
\hline 2 & $\begin{array}{l}\text { Chromolaenaodorata (Linn, King \& } \\
\text { Rob.) }\end{array}$ & Astereceae & Medicinal $^{\mathrm{a}}$ & $3 \pm 7$ & $24 \pm 68$ & $60 \pm 23$ & $0 \pm 0$ & + & ++ & ++ & - \\
\hline 3 & Ageratum conzoide (Linn.) & Astereceae & Medicinal $^{\mathrm{a}}$ & $1 \pm 5$ & $8 \pm 21$ & $27 \pm 18$ & $49 \pm 19$ & + & + & + & +++ \\
\hline 4 & Andropogon species & Proteaceae & Medicinal $^{\mathrm{a}}$ & $1 \pm 2$ & $1 \pm 5$ & $21 \pm 12$ & $18 \pm 15$ & + & + & + & + \\
\hline 5 & Eleucineindica (Linn. \&Gaertn) & Proteaceae & Medicinal $^{\mathrm{a}}$ & $10 \pm 18$ & $16 \pm 18$ & $26 \pm 10$ & $9 \pm 13$ & + & + & + & + \\
\hline 6 & Mimosa species (Linn.) & Febaceae-Mimo & Medicinal $^{\mathrm{a}}$ & $0 \pm 0$ & $1 \pm 2$ & $3 \pm 3$ & $2 \pm 4$ & + & + & + & - \\
\hline 7 & Caloponiumтисипоides (Desv) & Febaceae-Papi & Medicinal $^{\mathrm{a}}$ & $20 \pm 15$ & $72 \pm 18$ & $75 \pm 10$ & $81 \pm 4$ & ++ & ++++ & +++ & ++++ \\
\hline 8 & SidaacutaBurm F. & Malvaceae & Medicinal $^{\mathrm{a}}$ & $3 \pm 9$ & $5 \pm 12$ & $8 \pm 6$ & $1 \pm 1$ & + & + & + & + \\
\hline 9 & Triumfettacordifolia (A. Rich) & Amarantheceae & Medicinal $^{\mathrm{a}}$ & $4 \pm 9$ & $7 \pm 10$ & $12 \pm 12$ & $2 \pm 3$ & + & + & + & + \\
\hline 10 & Cyanthula prostrate (Linn.) Brume & Amarantheceae & Medicinal $^{\mathrm{a}}$ & $0 \pm 0$ & $5 \pm 11$ & $15 \pm 12$ & $19 \pm 17$ & - & + & + & - \\
\hline 11 & Scopariadulcis Linn. & Scrophuriaceae & Medicinal $^{\mathrm{a}}$ & $9 \pm 36$ & $52 \pm 68$ & $69 \pm 30$ & $27 \pm 10$ & + & +++ & +++ & ++ \\
\hline 12 & Passiflorafoetida & Passifloraceae & Medicinal $^{\mathrm{a}}$ & $13 \pm 43$ & $68 \pm 44$ & $80 \pm 7$ & $84 \pm 7$ & + & ++++ & +++ & ++++ \\
\hline 13 & Androponontectorum & Poaceae & Foliage $^{c}$ & $7 \pm 20$ & $67 \pm 47$ & $81 \pm 4$ & $86 \pm 8$ & + & ++++ & +++ & ++++ \\
\hline 14 & Sabiceapyramidalis L. Andersson & Rubiaceae & Medicinal $^{\mathrm{b}}$ & $10 \pm 23$ & $59 \pm 36$ & $77 \pm 5$ & $74 \pm 5$ & + & +++ & +++ & ++++ \\
\hline 15 & Carex digitalis & Cyperaceae & Medicinal $^{\mathrm{a}}$ & $20 \pm 17$ & $72 \pm 18$ & $81 \pm 8$ & $82 \pm 7$ & ++ & ++++ & +++ & ++++ \\
\hline 16 & Pycreuspolystachyos & Cyperaceae & Lawn & $7 \pm 4$ & $76 \pm 21$ & $87 \pm 4$ & $75 \pm 3$ & + & ++++ & ++++ & ++++ \\
\hline 17 & Diodascandense & Rubiaceae & Medicinal $^{\mathrm{a}}$ & $3 \pm 14$ & $16 \pm 65$ & $20 \pm 35$ & $69 \pm 9$ & + & + & + & +++ \\
\hline 18 & Urenalabata (Linn.) & Malvaceae & Medicinal $^{\mathrm{a}}$ & $1 \pm 3$ & $1 \pm 6$ & $5 \pm 5$ & $28 \pm 1$ & + & + & + & ++ \\
\hline 19 & Psychotriaspecies & Rubiaceae & Medicinal $^{\mathrm{b}}$ & $1 \pm 3$ & $3 \pm 8$ & $5 \pm 5$ & $44 \pm 15$ & + & + & + & +++ \\
\hline 20 & Zonialatifolia SM & Febaceae.Pspi & Medicinal $^{\mathrm{a}}$ & $3 \pm 6$ & $12 \pm 21$ & $26 \pm 26$ & $22 \pm 6$ & + & + & ++ & ++ \\
\hline 21 & Centrosemapubescens (Benth) & Fabiaceae-caesel & Medicinal $^{\mathrm{a}}$ & $2 \pm 7$ & $11 \pm 16$ & $29 \pm 25$ & $26 \pm 3$ & + & + & + & ++ \\
\hline 22 & Cynodondoctylon & Graminae/Poaceae & Medicinal $^{\mathrm{a}}$ & $2 \pm 14$ & $2 \pm 8$ & $6 \pm 4$ & $57 \pm 3$ & + & + & + & +++ \\
\hline 23 & Heterotisrotundifolia & Melastomataceae & Medicinal $^{\mathrm{a}}$ & $1 \pm 8$ & $3 \pm 6$ & $10 \pm 7$ & $7 \pm 1$ & + & + & + & + \\
\hline 24 & Volkensiicordata & Polypodiaceae & Medicinal $^{\mathrm{a}}$ & $5 \pm 12$ & $12 \pm 14$ & $15 \pm 8$ & $5 \pm 1$ & + & + & + & + \\
\hline 25 & Euphorbia pilufera & Euphorbiaceae & Medicinal $^{\mathrm{a}}$ & $8 \pm 15$ & $14 \pm 12$ & $20 \pm 9$ & $26 \pm 3$ & + & + & ++ & ++ \\
\hline 26 & Euphorbia hirta & Euphorbiaceae & Medicinal $^{\mathrm{a}}$ & $1 \pm 5$ & $5 \pm 8$ & $19 \pm 10$ & $5 \pm 1$ & + & + & + & + \\
\hline 27 & Euphorbia hyssopifolia & Euphorbiaceae & Medicinal $^{\mathrm{a}}$ & $2 \pm 5$ & $7 \pm 5$ & $21 \pm 7$ & $23 \pm 1$ & + & + & + & ++ \\
\hline \multicolumn{4}{|c|}{ Overall Mean Species Frequency Distribution } & $5 \pm 1$ & $25 \pm 23$ & $36 \pm 12$ & $37 \pm 32$ & & & & \\
\hline
\end{tabular}

Source: Author's Field Work, (2015) Key: - = absent (-), += very scarce (1-19), ++ = scarce (20-49), +++= moderate (50-69) and ++++ = very abundant (70$100)$. 
In addition, it was generally observed that higher plant species diversity and frequency distribution occurred at the control site as compared to values recorded at various distances from the auto-mechanic workshop clusters investigated in this study. For instance, overall mean species frequency distribution at the reference $(0 \mathrm{~m})$ point was $5 \pm 1 \%$, $25 \pm 23 \%$ at $50 \mathrm{~m}$ and $36 \pm 12 \%$ at $100 \mathrm{~m}$ at the auto-mechanic workshop clusters in the Yenagoa Metropolis while the control site showed $37 \pm 32 \%$, respectively (Table 1 ). Impacts of anthropogenic activities around auto-mechanic workshop clusters in the Yenagoa Metropolis had negatively affected plant species' spatial distributional patterns in this present study. Furthermore, plant species distribution significantly varied between $0 \mathrm{~m}$ and $50 \mathrm{~m}$ with the control site but insignificantly varied with species' distribution encountered $100 \mathrm{~m}$ from the auto-mechanic workshop clusters.

The reference points $(0 \mathrm{~m})$ which were observed to generally contain lower plant species' diversity (Table 1) than $50 \mathrm{~m}$ and $100 \mathrm{~m}$, were observed to show fairly higher heavy metals concentrations with decreased distances $(\mathrm{Zn}, \mathrm{Cu}, \mathrm{Cd}$, $\mathrm{Cr}, \mathrm{Hg} \& \mathrm{Mn}$ ) or with increased distances (Ni \& Fe) from the auto-mechanic workshop clusters in the study area (Table 2). The first instance is a reflection of distance decay effects as higher $\mathrm{Zn}, \mathrm{Cu}, \mathrm{Cd}, \mathrm{Cr}, \mathrm{Hg}$ and $\mathrm{Mn}$ levels in soils upon which the plants grew correspondingly influenced higher species diversity with increasing distances at the auto-mechanic workshop clusters in this study. Topography, soil type, drainage characteristics and climatic factors as suggested by [9] could have been responsible for the latter scenario as impacts of heavy metal contamination [11] and localized physical disturbances by artisans working at the auto-mechanic workshop clusters had played significant roles.

Table 2. Mean Heavy Meta Levels in Soils in Yenagoa Metropolis.

\begin{tabular}{llll}
\hline Heavy & \multicolumn{3}{l}{ Distances from AMWCs in the Yenagoa Metropolis } \\
\cline { 2 - 4 } Metals & $\mathbf{0 m}$ & $\mathbf{5 0 m}$ & $\mathbf{1 0 0 m}$ \\
\hline $\mathrm{Pb}$ & $0.02 \pm 0.01$ & $0.02 \pm 0.01$ & $0.02 \pm 0.01$ \\
$\mathrm{Control}$ & $0.00 \pm 0.00$ & $0.00 \pm 0.00$ & $0.00 \pm 0.00$ \\
$\mathrm{Zn}$ & $0.27 \pm 0.13$ & $0.26 \pm 0.14$ & $0.23 \pm 0.05$ \\
$\mathrm{Control}$ & $0.25 \pm 0.02$ & $0.37 \pm 0.02$ & $0.40 \pm 0.02$ \\
$\mathrm{Cu}$ & $0.09 \pm 0.07$ & $0.07 \pm 0.04$ & $0.07 \pm 0.05$ \\
$\mathrm{Control}$ & $0.02 \pm 0.01$ & $0.02 \pm 0.01$ & $0.02 \pm 0.01$ \\
$\mathrm{Cd}$ & $0.02 \pm 0.02$ & $0.01 \pm 0.02$ & $0.01 \pm 0.01$ \\
$\mathrm{Control}$ & $0.00 \pm 0.00$ & $0.00 \pm 0.00$ & $0.00 \pm 0.00$ \\
$\mathrm{Co}$ & $0.01 \pm 0.01$ & $0.01 \pm 0.01$ & $0.01 \pm 0.01$ \\
$\mathrm{Control}$ & $0.01 \pm 0.01$ & $0.00 \pm 0.00$ & $0.00 \pm 0.00$ \\
$\mathrm{Cr}$ & $0.02 \pm 0.03$ & $0.01 \pm 0.01$ & $0.01 \pm 0.01$ \\
$\mathrm{Control}$ & $0.00 \pm 0.00$ & $0.00 \pm 0.00$ & $0.00 \pm 0.00$ \\
$\mathrm{Ni}$ & $0.03 \pm 0.05$ & $0.04 \pm 0.06$ & $0.08 \pm 0.13$ \\
$\mathrm{Control}$ & $0.01 \pm 0.01$ & $0.01 \pm 0.01$ & $0.01 \pm 0.01$ \\
$\mathrm{Hg}$ & $0.02 \pm 0.01$ & $0.01 \pm 0.01$ & $0.01 \pm 0.01$ \\
Control & $0.00 \pm 0.00$ & $0.00 \pm 0.00$ & $0.00 \pm 0.00$ \\
$\mathrm{Mn}$ & $0.03 \pm 0.02$ & $0.02 \pm 0.01$ & $0.02 \pm 0.01$ \\
Control & $0.01 \pm 0.01$ & $0.01 \pm 0.01$ & $0.01 \pm 0.01$ \\
Fe & $1.05 \pm 0.73$ & $1.28 \pm 1.10$ & $1.46 \pm 1.47$ \\
$\mathrm{Control}$ & $1.49 \pm 0.03$ & $1.55 \pm 0.03$ & $1.56 \pm 0.02$ \\
\hline
\end{tabular}

\section{Conclusions}

This study has been able to provide a checklist of plant species found growing within and around soils of automechanic workshop clusters and a control site in the Yenagoa Metropolis, Bayelsa State, Nigeria. Discharge of heavy metal-bearing substances like waste engine oils, transmission fluids, waste electrodes, scrap metal deposits, and a host of other waste substances is a common practice around auto-mechanic workshop clusters in Nigeria [1]. However, despite exposure to discharge of heavy metalbearing substances upon vulnerable soils with propensities for increasing soil heavy metal levels and consequent bioaccumulation into plant's tissues, some indigenous plant species were observed to be capable of growing luxuriantly within such contaminated environments. These plant species show evidence of genetic tolerance to heavy metal contaminations, hence good candidates for such contaminant's remediation from vulnerable soils. Thus, plant species that featured more prominently across all automechanic workshop clusters are considered good choices for studies that focus on screening for heavy metal phytoremediators in the study area.

This study has shown that plant species like Sc. dulcis (Scrophuriaceae), C. digitalis (Cyperaceae), Py. Polystachyos (Cyperaceae), A. tectorum (Poaceae), $P$. foetida (Passifloraceae), S. paramidalis (Rubiaceae), as well as C. mucunoides (Febaceae) could be considered as local plant species of choice in any investigation focusing on screening of plants for heavy metal-related studies around auto-mechanic workshop cluster in the Yenagoa Metropolis since despite exposure to prevailing natural and anthropogenic conditions, they still grew vigorously, showed fair dominance levels and good frequency distributions in the study area, respectively. Finally, it was generally observed that higher heavy metal concentrations could be responsible for the lower plant species distribution and frequencies found within the reference point $(0 \mathrm{~m})$ as compared to plant species frequency distribution noticed farther distances $(50 \mathrm{~m}$ and $100 \mathrm{~m}$ ) away from the auto-mechanic workshop clusters with comparably lower heavy metal levels and where anthropogenic impacts were felt less.

\section{References}

[1] Amukali, O. (2018) Spatial Distribution of Heavy Metals in Soils and Plants growing around Auto-mechanic Workshop Clusters in the Yenagoa Metropolis. A Ph.D Dissertation submitted to the Post Graduate School of Niger Delta University, Amassoma, Bayelsa State, Nigeria. 278p.

[2] Anoliefo, G. O., B. Ikhajiagbe, B. O. Okonofhua and F. V. Diafe, (2006) Eco-Taxonomic Distribution of Plant Species around Motor Mechanic Workshops in Asaba and Benin City, Nigeria: Identification of Oil Tolerant Plant Species. African J. Biotechnol., 5: 1757-1762. 
[3] Arshad, M. K., Q. Rahmatullah, F. Q. Mirza, M. Mubashrah, Y. Muhammad and S. Zafeer (2015) Floristic Checklist of District Kotli, Azad, Jammu and Kashmir. Pak. J. Bot., 47 (5): $1-12$.

[4] Bariweni, P. A. and O. Amukali (2017) Wetlands Cover Changes in Yenagoa Metropolis, Niger Delta. Portharcourt Journal of Social Sciences. 7: 1-7.

[5] Bariweni, P. A., W. L. Izonfuo and E. N. Amadi (2002). Domestic Waste Levels and Assessment of their Current Management Strategies in Yenagoa Metropolis. Glob. J. Environ. Sci. 1 (1): 15-19.

[6] Ehigiamusoe, R. E. (2013) A Herbarium of Nigerian Medicinal Plants. University of Calabar Press, Calabar, Nigeria. 573p.

[7] Gibson, J. P. and A. J. Poland (1988) Zinc intolerance in Panicum virgatum $\mathrm{L}$. (Switch grass) from the Pitcher Mine Area. Proc. Oklahoma Academy Sci. 68: 45-48.

[8] Gill, L. S. (1992) Ethnomedical Uses of Plants in Nigeria. Union Press of University of Benin, Benin City, Nigeria. 276p.

[9] Imevbore, A. A. A. and S. A. Adeyemi (1981) Environmental Monitoring in relation to Pollution and Control of Oil Pollution. In: Proc. Seminar on the Petroleum Industry and the Nigerian Environment. 6: 135-142.

[10] Khan, Q., W. I. Qaseew and I. Saqiba (2015) Floristic Checklist of the District Kotli, Azad Jammu and Kashmir. Pak. J. Bot., 47 (5): 1957-1968.

[11] Merkl, N., R. Schultze-Kraft and C. Infante (2005) Phytoremediation in the Tropics-Influence of Heavy Oil on Root Morphological Characteristics of Graminoids. Environ. Pollut. 138: 86-91.
[12] National Census: Federal Republic of Nigeria Gazzete, (2007).

[13] Obadoni, B. O., N. E. Edema, H. Erheni, E. Ogie-Odia and O. Amukali (2009) A Checklist of the Flora of Edaphic Grasslands in the Rainforest Belts of Edo and Delta States of Nigeria. World Rural Observations. 1 (1): 43-49.

[14] Obafemi, A. A. and P. Omiumu (2014) Analysis of Immigrants' Residential Preferences and Ethnic Segregation in Yenagoa Metropolis. Research in Humanities and Social Sciences. 4 (19): 13-20.

[15] Okeke, C. U., E. O. Ekanem and A. M. Harami (2014) Bioaccumulation of Heavy Metals in Mechanic Workshops. Int. J. Maths \& Phy. Sci. Res. 2 (1): 58-65.

[16] Rivers and Bayelsa States Environmental Action Plan (1998). Description of Soil Types in the State Environmental Action Plan Report for Rivers and Bayelsa States in the Niger Delta Area, Nigeria.

[17] Shell Petroleum Development Company (2006) Final Report of the Environmental Impact Assessment (EIA) of Rumuekpe (OML 22) and Etelebou (OML 28) 3D Seismic Survey. SPDC Press, PHC. 393p.

[18] Soladoye, M. O., E. C. Chukwuma, J. A. Fagbenro and E. O. Adelagun (2015) A Checklist of Angiosperm Diversity of Bowen University Campus, Iwo, Osun State, Nigeria. Journal of Plant Sciences 10 (6): 244-252.

[19] World Conservation Monitoring Centre (WCMC) (1992) Global Biodiversity: Status of the Earth's Living Resources. Chapman and Hall, London.

[20] Wikipedia (2014) Yenagoa. http://en.wikipedia.org Downloaded 18/10/2014. 